Available online at GSC Online Press Directory

GSC Biological and Pharmaceutical Sciences

e-ISSN: 2581-3250, CODEN (USA): GBPSC2

Journal homepage: https://www.gsconlinepress.com/journals/gscbps

(RESEARCH ARTICLE)

\title{
The diversity of fresh water snail fauna in Kiri dam, Adamawa State, North Eastern Nigeria
}

\author{
Sanu Kaleson Meshack ${ }^{1,}{ }^{*}$, Istifanus William Aliyu ${ }^{2}$, Musa Maryam Suleiman ${ }^{2}$ and Mao Panda Sam ${ }^{2}$ \\ ${ }^{1}$ Department of Science Laboratory Technology, Adamawa State Polytechnic Yola, \\ Adamawa State, Nigeria. \\ ${ }^{2}$ Department of Biological Sciences, Abubakar Tafawa Balewa University Bauchi, Bauchi State, Nigeria.
}

Publication history: Received on 29 April 2020; revised on 07 May 2020; accepted on 09 May 2020

Article DOI: https://doi.org/10.30574/gscbps.2020.11.2.0118

\begin{abstract}
Freshwater Snails are crucial in assessing the ecological status of water bodies, besides their economic, public and veterinary health importance. Hence, the need to study the occurrence, and diversity of freshwater snails in Kiri dam where there is paucity of such information becomes imperative. Accordingly, this study was carried out between December, 2016 and July, 2018. Snails were searched for in the five contact sites identified using long handle metal scoop nets in accordance with standard procedure. Snails recovered were examined for natural infections. Eleven (11) different fresh water snail species were encountered including Bulinus globosus, Bulinus truncatus, Biomphalaria pfeifferi, Lymnaea natalensis, Lanistes ovum, Lanistes varicus, Pila ovata, Melanoides maculata, Melanoides tuberculata, Bellamya unicolor and Gabiella tchadiensis of the eleven different snail species examined, only Bulinus globosus Bulinus truncatus and Biomphalaria pfeifferi shed schistosome cercariae. The other 8 species did not have any natural infections. The study revealed that Kiri Dam harbours diverse species of fresh water snails including those of public health importance. The presence of naturally infected snails indicates that the people engaging in various activities in the dam, are predisposed to infections harboured by these snails.
\end{abstract}

Keywords: Freshwater snails; Kiri Dam; Adamawa State

\section{Introduction}

The development and management of dams has numerous social and economic benefits such as irrigation, power generation, fishing, transportation and tourism. However, damming of rivers and streams to build such reservoirs gives rise to significant modification in the natural ecology of the original water bodies [1]. It creates new biotopes which are conducive for breeding of fresh water snails. Some of these snails have been known to play significant roles in medical and veterinary health spheres because they serve as intermediate hosts for helminth parasites that cause diseases such as schistosomiasis, fascioliasis, paragonimiasis, and angiostrongylosis among others. The transmission of these infections takes place only in places where fresh water snail intermediate hosts are present, and where there are contact between the population and the infected water. Disease transmission is therefore facilitated by availability of surface water throughout the year and this is provided by dams.

Several studies in Nigeria have associated increase in prevalence of schistosomiasis and other snail borne infections with provision of dams. Some of these include those of Akogun and Akin [2] at the Savannah Sugar plantation staff village in Adamawa State, Adamu et al., [3] at Piro village near Gubi Dam in Bauchi State, Abdulkadir et al [4] at Gimbawa Dam, Kaduna State, Timothy et al., [5] at Zobe Dam, Dutsin-Ma, Katsina State and Sunday et al., [6] at Dadinkowa manmade reservoir in Gombe State. All of these reports have observed an increased trend in transmission of snail borne

\footnotetext{
${ }^{*}$ Corresponding author: Sanu Kaleson Meshack
} 
parasitic infections or the occurrence of freshwater snail intermediate hosts of parasites of public health importance where they hadn't been earlier observed.

There is currently paucity of information on diversity, distribution and disease transmission potential of freshwater snails in the Kiri Dam. This information is none the less vital in planning any future intervention should the need arise. We therefore report here the freshwater snail fauna in Kiri Dam, Adamawa State, North Eastern Nigeria.

\section{Material and methods}

\subsection{Description of study area}

The study was carried out in Kiri Dam located in Shelleng Local Government Area of Adamawa State. (Fig.1) Shelleng is situated along latitude $9^{\circ} 53^{\prime} 51 \mathrm{~N}$ and longitude $12^{\circ} 0^{\prime} 32 \mathrm{E}$ Greenwich meridian, with population of 148,490 . The dam was constructed in the year 1982, on the river Gongola. It is $1.2 \mathrm{~km}$ long, having $20 \mathrm{~m}$ high zone embankment with internal clay blanket. It has a maximum depth of $10 \mathrm{~m}$ and an effective storage capacity of 615 million litres. It lies between the coordinates of $9^{\circ} 50^{\prime} \mathrm{N} 12^{\circ} 0051^{\prime \prime} \mathrm{E}$. The area has sedimentary rocks, limestone and Ignite. The landforms of the area are characterized by extensive floodplains and swamps. Most of the locations are liable to flooding, water logging or swamps. Kiri has marked dry and rainy seasons typical of tropical climate. The rainy season last from April to October, but sometimes May to September. The mean annual rainfall is between 759-1011 mm. The driest and coldest months are December and January with relative humidity of $13 \%$. Although temperature varies from place to place due to altitude, the average minimum and maximum temperatures is $25^{\circ} \mathrm{C}$ and $40^{\circ} \mathrm{C}$ respectively.

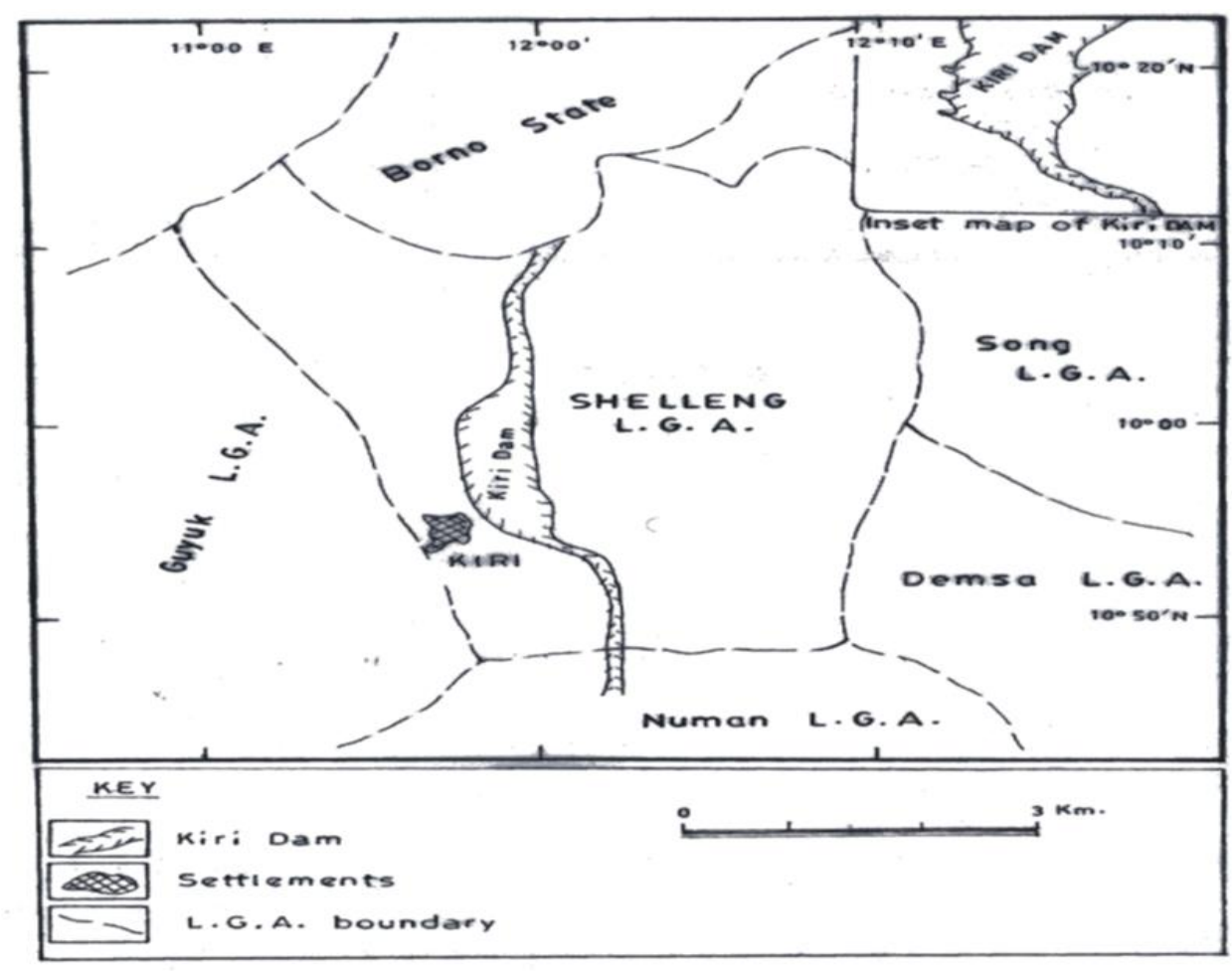

Figure 1 Map of Shelleng Local Government Area showing location of Kiri dam

Source: Ministry of Land and Survey, Adamawa state

\subsection{Snail sampling and identification}

Snail sampling from the identified water contact sites A-E was done twice a month for a period of 20 months from December, 2016 to July, 2018. On each sampling day, each site was searched carefully for 30 minutes using a long handle metal scoop net as described by [7]. Snails collected were kept in plastic containers and brought to the laboratory and were identified to species level on the basis of their morphological characteristics with reference to the standard keys of [8]. Thereafter, snails were shed for possible natural infections. 


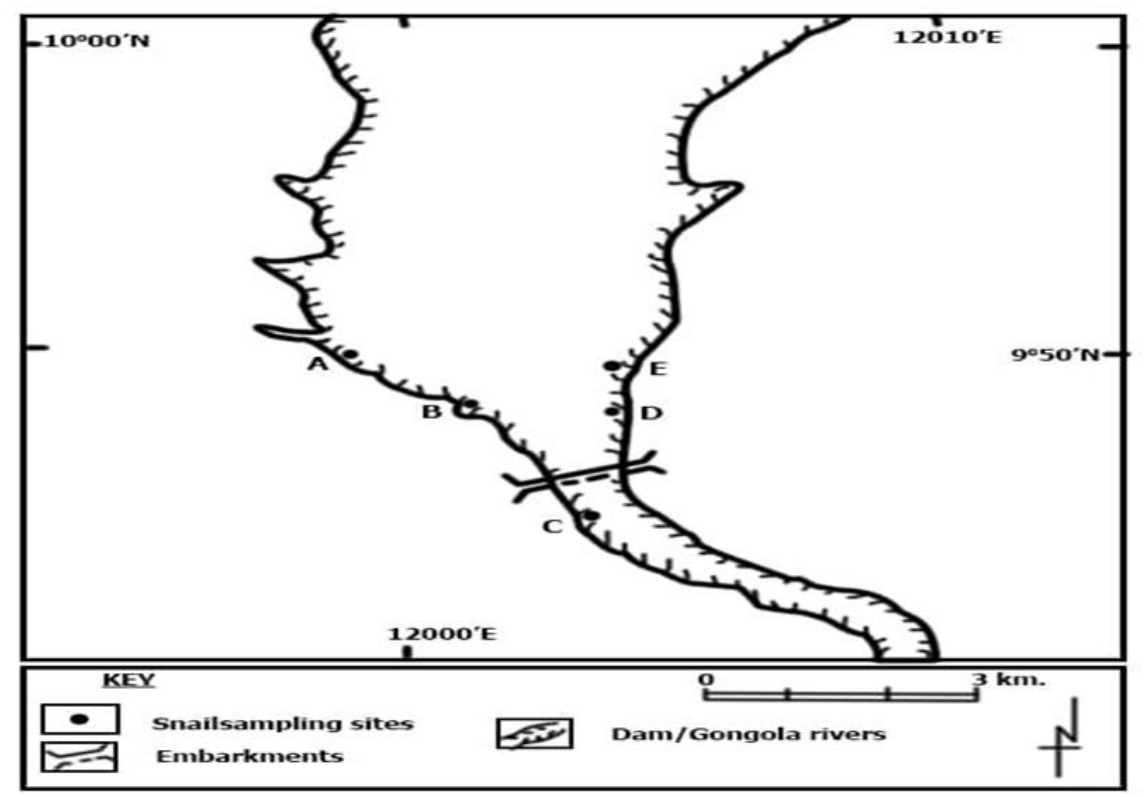

Figure 2 Kiri dam showing location of study sites A - E.

Source: Ministry of Land and Survey, Adamawa State

\section{Results}

Altogether Eleven (11) different snail species were encountered in the dam. These include Bulinus globosus, Bulinus truncatus, Biomphalaria pfeifferi, Lymnaea natalenses, Lanistes ovum, Lanistes varicus, Melanoides meculata, Melanoides tuberculata, Gabiella tchadiensis, Bellamya unicolor, and Pila ovata. Bulinus globosus, and Biomphalaria pfeifferi were very common in all snail sampling sites in the dam, while Bulinus truncatus was uncommon (Table 1). Similarly, Gabiella tchadiensis, Lanistes ovum, Melanoides tuberculata, and Pila ovata were also common while Bellamya unicolor Lanistes varicus, and Melanoides meculata were uncommon as well (Table 1). The morphology of the snails encountered is depicted in Fig.3. Of the 11 species found, Bulinus globosus, Bulinus truncatus, and Biomphalaria pfeiffeiri shedded cercariae typical of schistosomes.

Table 1 Diversity of fresh water snails found in Kiri dam, Adamawa state, north eastern Nigeria.

\begin{tabular}{|c|c|c|c|c|c|c|}
\hline \multirow[b]{2}{*}{ Sub-Class } & \multirow[b]{2}{*}{ Snail species } & \multicolumn{5}{|c|}{ Sampling sites } \\
\hline & & A & B & $\mathbf{C}$ & D & $\mathbf{E}$ \\
\hline \multirow[t]{4}{*}{ Pulmonata } & Bulinus globosus & +++ & +++ & +++ & +++ & +++ \\
\hline & Bulinus truncatus & + & + & + & + & + \\
\hline & Biomphalaria pfeifferi & +++ & +++ & +++ & +++ & +++ \\
\hline & Lymneae natalensis & + & ++ & ++ & + & ++ \\
\hline \multirow[t]{7}{*}{ Prosobranchiata } & Bellamya unicolor & + & + & + & + & + \\
\hline & Gabiella tchadienses & ++ & + & ++ & + & ++ \\
\hline & Lanistes ovum & ++ & + & + & + & ++ \\
\hline & Lanistes varicus & + & + & + & + & ++ \\
\hline & Melanoides meculata & + & + & + & + & ++ \\
\hline & Melanoides tuberculata & ++ & + & + & + & + \\
\hline & Pila ovata & ++ & ++ & + & + & + \\
\hline
\end{tabular}

Key: - not found, $+=$ uncommon, $++=$ common, $+++=$ very common 


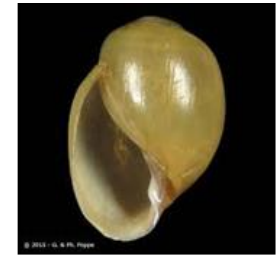

Fig3a: Bulinus globosus

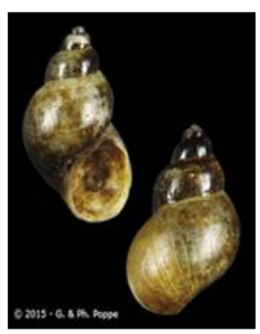

Fig3f: Gabiellatchadiensis

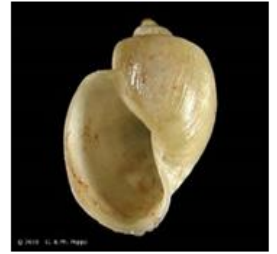

Fig3b: Bulinus truncatus

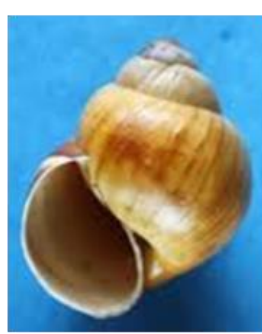

Fig3g:Lanistes ovum

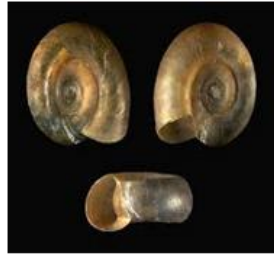

Fig3b: Bulinus truncatus

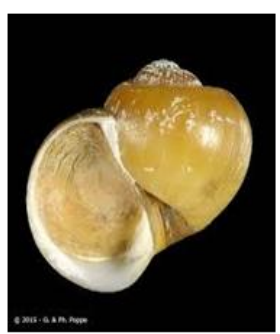

Fig3h: Lanistes varicus

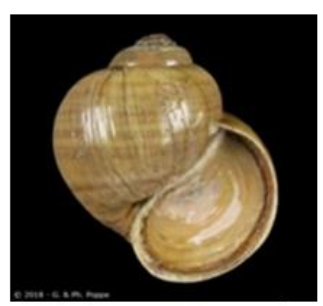

Fig3k: Pila ovata
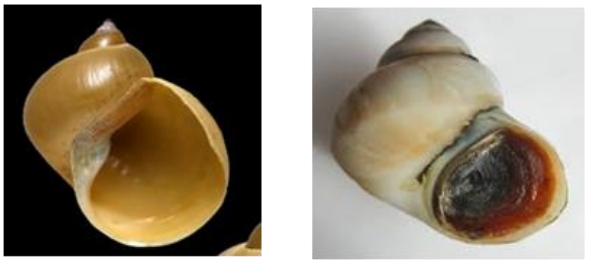

Fig3d: Lymneae natalensis Fig3e: Bellamya unicolor

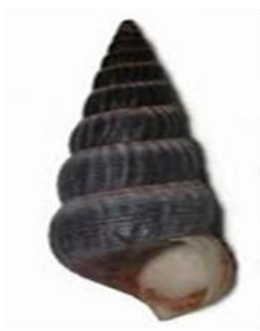

Fig3i:Melanoides maculata

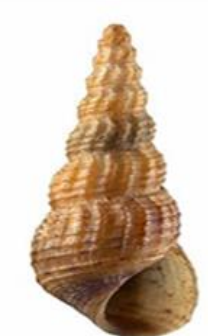

Fig3): Melanoides tuberculata

Figure 3 Shell characteristics of the 11 snail species encountered in Kiri Dam

Table 2 Infectivity status of fresh water snails encountered in Kiri dam, Adamawa state, north eastern Nigeria

\begin{tabular}{llll}
\hline Snails species & No. examined & No. Infected & \%infected \\
\hline Bulinus globosus & 1539 & 394 & 29.7 \\
Bulinus truncatus & 485 & 56 & 11.5 \\
Biomphalaria pfeifferi & 2016 & 358 & 7.8 \\
Lymneae natalensis & 524 & 0 & 0.0 \\
Bellamya unicolor & 156 & 0 & 0.0 \\
Gabiella tchadienses & 408 & 0 & 0.0 \\
Lanistes ovum & 609 & 0 & 0.0 \\
Lanistes varicus & 38 & 0 & 0.0 \\
Melanoides meculata & 99 & 0 & 0.0 \\
Melanoides tuberculata & 280 & 0 & 0.0 \\
Pila ovata & 566 & 0 & 0.0 \\
\hline Total & $\mathbf{6 7 2 0}$ & $\mathbf{8 0 8}$ & $\mathbf{1 2 . 0}$ \\
\hline
\end{tabular}

\section{Discussion}

The results of this study show that Kiri dam harbours many species of freshwater snails. To the best of our knowledge, this is the first attempt to document the diversity of freshwater snail fauna in Kiri dam. All the 11 species encountered are common freshwater snails which have been reported from various parts of Nigeria [6,9-13]. Thus, no strange snail species were observed. It is interesting that of the 11 species found, only three of them (Bulinus globosus, Bulinus 
truncatus, Biomphalaria pfeifferi) shed cercariae. It is therefore no wonder that in a different but related study in the area by the same authors both urinary and intestinal schistosome infections were common. Thus, the occurrence of naturally infected Bulinus and Biomphalaria species strongly suggest that transmission of both Schistosoma haematobium and S. mansoni is on-going in the area. A high level of water contact activity was also observed during the study and this is an important epidemidogical factor enhancing the transmission of infection.

The occurrence of Lymneae natalensis in the dam is note worthy although they did not carry any natural infections during the study it is a known intermediate host of Fasciola gigantica. Since cattle were observed drinking water and grazing along the banks of the dam, there is therefore a high possibility of these snails becoming infected thereby establishing a transmission cycle. Consequently, there is need to clarify whether active transmission of fascioliasis occurs in the area and to elucidate on the transmission pattern.

The presence of Melanoides species in Kiri dam is also note worthy. In particular Melanoides tuberculata is a known first intermediate host of the lung fluke Paragonimus africanus and P. uterobilateralis. Although the snail did not shed any cercariae it has the potential of being infected in future. Thus, it should be carefully monitored to determine its transmission status.

Occurrence of Bellamya unicolor, Gabiella tchadiensis, Lanistes ovum, Lanistes varicus, and Pila ovata in high abundance may be related to human and animal activities in the dam. This agrees with the report of [11] in the Gimbawa dam Kaduna State and that of [12] in Imo State, Nigeria. Even though they are not of any known medical or veterinary importance, they are still important because together with those having economic importance they are herbivores removing vegetative biomass which may affect the standing crop and distribution of primary producers in the aquatic ecosystem.

\section{Conclusion}

This study has shown that Kiri dam habours a variety of freshwater snails some of which are known intermediate host of trematode parasites. In light of this, further studies to determine their precise roles in disease transmission as well as transmission patterns is desirable. In addition, snail surveys should regularly be undertaken so as to keep track of species diversity in the dam towards possible control.

\section{Compliance with ethical standards}

\section{Acknowledgments}

We are grateful to the Ministry of Water Resources, Management of Shelleng Local Government Area as well as the Village Head of Shelleng for permission to undertake this work. Immense gratitude is also extended to the Department of Biological Sciences, and Animal Ethical Committee of Abubakar Tafawa Balewa University, Bauchi and that of the Department of Science Laboratory Technology, Adamawa State Polytechnic, Yola for liberal provision of laboratory facilities.

\section{Disclosure of conflict of interest}

We declare that there are no conflict of interest in connection with this paper.

\section{References}

[1] Owojori OJ, Asaolu SO and Ofoeze EI. (2006). Ecology of freshwater Snails in Opa Reservoir and Research farm ponds at Obafemi Awolowo University Ile-Ife, Nigeria. Journal of Applied Sciences, 6(15), 3004-3015.

[2] Akogun OB and Okin, BN. (1993). The ecology of freshwater snails in Agro-Industrial Estate in Yola, Nigeria. Nigerian Journal of Parasitology, 14, 75-80.

[3] Adamu US, Panda SM and Okafor A. (2004). Studies on human water contact pattern and other schistosomiasis predisposing factors in Gubi Dam. Science Forum: Journal of Pure and Applied Sciences, 7(2), 197-202.

[4] Abdulkadir FM, Maikaje DB and Umar YA. (2017). Ecology and Distribution of Freshwater Snails in Gimbawa Dam, Kaduna State, Nigeria. Nigerian Journal of Chemical Research, 22(2), 98-106. 
[5] Timothy A, Emmanuel A and Elaigwu AM. (2018). Population Dynamics, Diversity and Distribution of Freshwater Snails in Zobe Dam, Dutsin-Ma, North-Western Nigeria. Asian Journal of Environment and Ecology, 8(4), 117.

[6] Sunday ID, Istifanus WA and Adamu BS. (2019). The Freshwater Snail Fauna of Dadinkowa man made Reservoir, Gombe State Nigeria. International Journal of Fauna and Biological Studies, 6(5), 31-35.

[7] Panda SM, Istifanus WA and Suleiman MM. (2014). Observations on some morphological variations among different Bulinus globosus populations in North Eastern Nigeria. International Journal of Advancement in Biological Sciences, 6 (2), 65-75.

[8] Brown DS. (1994). Freshwater Snails of Africa and their Medical Importance, Revised 2nd Edition, Taylor and Francis Ltd., London, 609.

[9] Ngele K, Kalu E, Ukwey M and Onyeukwu C. (2012). A Survey of freshwater snails: the intermediate hosts of schistosomiasis in Bende Local Government Area, Abia State, Nigeria. International Journal of Science and Nature, 3(4), 879-882.

[10] Omonijo AO, Asaolu SO and Ofozie IE. (2016). Ecology of Schistosoma Snail Vectors in Ado-Ekiti Local Government Area of Ekiti State Nigeria, International Journal of Pure and Applied Zoology, 4(1), 77-84.

[11] Okeke OC and Ubachukwu PO. (2013). Urinary schistosomiasis in urban and semi-urban communities in SouthEastern Nigeria.Iranian Journal of Parasitology, 8 (3), 467-473.

[12] Salawu OT and Odaibo AB. (2014). Urogenital schistosomiasis and urological assessment of haematuria in preschool-aged children in rural communities of Nigeria. Journal of Pediatric Urology, 10 (1), 88-93.

[13] Awosolu OB. (2016). Epidemiology of Urinary Schistosomiasis and Knowledge of Health Personnel in Rural Communities of South-Western Nigeria. Journal of Parasitology and Vector Biology, 8(10), 99-106.

[14] Njoku-Tony F. (2011). Effect of some physico-chemical parameters on abundance of intermediate snails of animal trematodes in Imo State, Nigeria. Researcher, 3(4), 15-21.

\section{How to cite this article}

Sanu KM, Istifanus WA, Musa MS and Mao PS. (2020). The diversity of fresh water snail fauna in Kiri dam, Adamawa State, North Eastern Nigeria. GSC Biological and Pharmaceutical Sciences, 11(2), 99-104. 